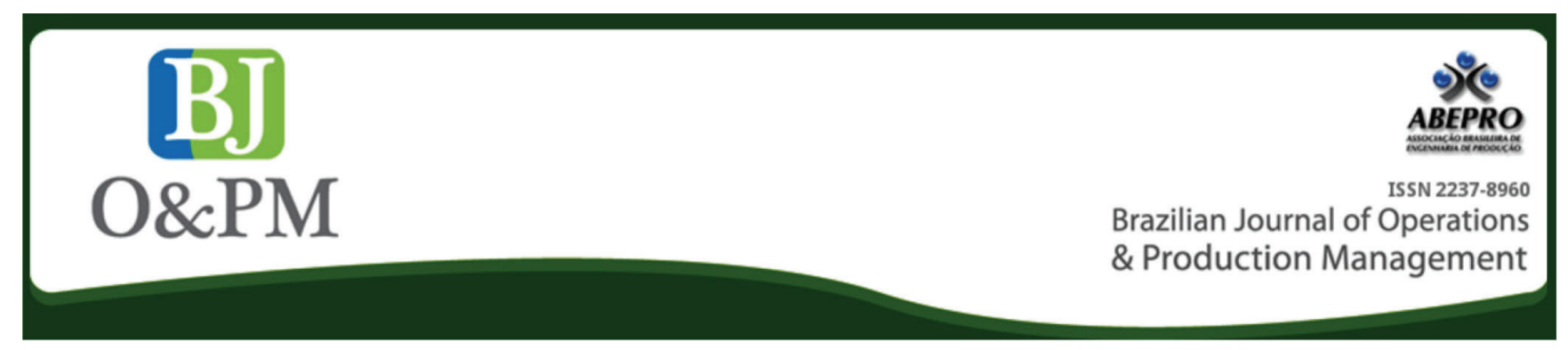

\title{
THE EFFECT OF MANAGERS' POWER ON EMPLOYEES' ENTREPRENEURSHIP: AN EMPIRICAL STUDY IN THE PUBLIC OFFICES OF IRAN
}

Farhad Mahbobkhah mahbobkhah_farhad@yahoo.com Department of Government Management, Bonab Branch, Islamic Azad University, Bonab, Iran

\begin{abstract}
Objectives: The aim of this paper is to examine the effect of managers' power on employees' entrepreneurship in the public offices by using five dimensions of power (Coercive, expert, legitimate, referent, and reward) to give constructive suggestions for situation improvement through identifying powers affecting employees' entrepreneurship.

Design/Methodology/Approach: Considering the research objective, it is an applied study, and regarding data collection and the data analysis method, it is a descriptive-correlational study which has analyzed data through structural equations modeling with partial least squares (PLS) approach. Data were collected using two questionnaires including managers' power and employees' entrepreneurship. A sample of 600 employees was selected from the public offices of Iran. Data were analyzed using structural equation modeling and Amos software.

Results: The finding revealed that reward power, referent power, expert power and legitimate power had a positive and significant effect on employees' entrepreneurship, but the coercive power had not significant effect on it.

Limitations: Among limitations of the current research are the big size of the statistical population that made it difficult to collect data, as well as the existence of different cultures in the statistical population which could partly affect the results of the research.

Practical implications: Research findings can be used to improve the entrepreneurship of employees in government organization.

Originality/value: Authors confirm that the current research and its results are genuine and have been published nowhere so far. The proposed structural model in the current research can be used in government departments and improve the entrepreneurship status of employees in the organization.
\end{abstract}

Keywords: managers' power, employees' entrepreneurship, Iran 
Brazilian Journal of Operations \& Production Management

Volume 16, Número 4, 2019, pp. 617-626

DOI: 10.14488/BJOPM.2019.v16.n4.a7

\section{INTRODUCTION}

At the present, rapid changes in science and technology have created a lot of problems in social and economic systems. These changes have created threats and opportunities that require creative solutions when faced.

Economists, sociologists and management scientists have proposed different definitions and conceptual frameworks for the entrepreneurship process. The study of entrepreneurship can be defined as the study of opportunity resources. In fact, entrepreneurship process is defined as the process of discovery and assessment, and the use of job opportunities (De Amorim Braga et al., 2018). Entrepreneurship is one of survival forms of today's organization. entrepreneurship as the process of creating something different from value, by devoting the necessary time and effort, assuming the accompanying financial, psychological and social risks, and receiving the resulting rewards of monetary and personal satisfaction.

Due to the importance of entrepreneurship, the government has provided much Entrepreneurial assistance, such as funding, physical infrastructure and business advisory services through various entrepreneurial bodies, such as the Graduate Entrepreneur fund, the National Institute of Entrepreneurship, and the Permodalan Usahawen Dumiputera Nasional through the "skim Garduan", which is a pioneer graduate program (Muhammad et al., 2011; Sandhu et al., 2010). Therefore, adopting an attitude to ensure the organization's success is necessary (Daft, 2000). Entrepreneurship is an opportunity-based way of thinking and acting (Jena and Sahoo, 2014). In spite of this public belief that entrepreneurship only exists in the public sector, studies have shown that this category is also seen in nonprofit organizations (private sector). Currently, organizations in which the flow of innovation and dynamism exists are more successful than others. To achieve such a situation a manager and leader who can significantly affect the employees' performance is needed (Analoui et al., 2009). They can affect the employees' attitudes through the powers they have at their disposal and lead to the occurrence of different behaviors in the organization, such as strengthening entrepreneurial characteristics, reducing absence from work, and increasing efficiency (Watson and Papamarcos, 2002). Employees show mutual behaviors against managers (Coyle-Shapiro and Marrow, 2006); therefore, managers can attain competitive superiority through human resources with entrepreneurship characteristics and guarantee their success. On the other hand, in order to cope with the sudden changes and competitive space, it is essential to adopt an entrepreneurial attitude to ensure the organization's success. To this purpose, managers who are capable of properly using their power resources and tools are needed.
On the other hand, the power of managers is one of the concepts that affect the performance of the organization and management. Montana and Charnov (2008) state that power is composed of five components, such as coercive, expert, legitimate, referent, and reward. Generally, it should be said that the use of power requires a special skill and it can be considered as an art to increase and strengthen the given cases in government organizations. Power may be used vertically or horizontally in social systems. It is likely that power is interpreted among organizational units and their relationships, and/or gains meaning in the relationships between the upstream and downstream (Pfeffer, 1994).

Some questions may arise in our minds: what is power? Where can it be seen in organizations? Several centuries ago Machiavelli wrote his celebrated book, The Prince, in which he dealt with the principles of power as used by rules. Today power is an issue that has been the focus of attention for those studying politics over the years. in 1959 French and Raven defined the different types of power.

Power is a neutral force. It may be perceived as either positive or negative, depending on the frame of resource, life experiences, and objectivity of the people involved.

Mintzberg (1983) sees power as the ability to achieve organizational outcomes; the manager in the role of leader has a significant impact on the performance of a group. Undoubtedly, power is one of the ways in which leaders and managers can influence the behavior of their followers. In fact, power is a key for manager to provide an effective basis in the organization. The managers are policy makers in the organizations and the performance of these organizations has been related to their power. In today's world, organizations' stability faces many threats. Perhaps some of these threats can be covered by innovation and entrepreneurship (Minatogawa et al., 2018). Considering the materials reviewed and given the conditions and situation of government departments, as well as regarding the existence of massive capitals and God-given resources, unfortunately, there are a lot of problems in Iran's government departments whose main reason is the improper use of human recourses, and it seems that by using the proper power bases by managers and modifying managers' selection in these organizations, some of the problems can be resolved. Therefore, the problems mentioned above caused the researcher to investigate the effect of managers' power resources (legitimate, reward, coercive, referent, and expert) on the employees' entrepreneurship with the aim to improve the status of these organizations so that at least some constructive suggestions can be presented to improve the status. 


\section{THEORETICAL BACKGROUND AND RESEARCH HYPOTHESES}

In the following paragraphs, the literature of managers' power and employees' entrepreneurship are studied.

\subsection{Research on managers' power}

The study of managers' power and its impact is very important to understand organizations' performance.

The way organizational sub-units and employees are controlled is related to the issue of power and influence. Originated in Latin, power, which means to be able, has been associated with the ability to produce desired outcomes (Guinote, 2010). It is often defined as the ability of a person to influence others (De Dreu and Van Kleef, 2004; French and Raven, 1959; Lewin, 1941; Vescio et al., 2003) or control outcomes by providing or withholding resources valuable to others (Galinsky et al., 2003; Keltner et al., 2003; Thibaut and Kelley, 1959; Weber, 1947). The study of power and its effects and the way it is used in the government organizations is a very important issue (Pinnow, 2011). The way in which the organization's sub-units and individuals are controlled is associated with the power issue and its effect. It should be said that power is a function of influence without threat (Erkutlu and Chafra, 2016). Influence is associated with respect in this regard (Drea et al., 1993). For example, people's needs are satisfied when they are respected, so it can be argued that the managerial power is positive in this regard (Cho, 2006). In this study, the theory of French and Raven (1959) has been selected to managers' power. French and Raven have presented the most important analysis on power resources. They have identified five powers, including legitimate, reward, coercive, referent, and expert powers in organizational environments that are considered as the basis of many research studies. Legitimate power is the power that originates in the organizational position and status of individuals. Reward power refers to the ability to provide things that others like. Coercive power is based on the employees' fear and horror and is dependent on fear and punishment. Referent power is based on the individual's personality, and it is said that whenever the employees attribute good characteristics, such as honesty and trusteeship to their boss, the boss has the referent power. Expert power is the ability to control the behavior of another individual through knowledge and the experience he/she lacks but needs to have.

\subsection{Research on employees' entrepreneurship}

Entrepreneurship has been recognized as the engine of countries' development. (Schumpeter, 1934), Referred to as the "Fundamental phenomenon of economic development", entrepreneurship is responsible for technological innovation; exploitation of opportunities; and coping with uncertainty and risk taking.

Researchers in Entrepreneurship studies, factors affecting entrepreneurial behavior divided into three categories: social, environmental, and personal. In the Social factors model, factors such as personal history, family history, class career, recent experience of life, growth environment, and etc. are important. The environmental factors model, in turn, focuses on factors such as money value, tax, and indirect benefits.

On the other hand, the individual factors model that is widely known as features model focuses on personality traits (Gurol and Atsan, 2006). The approach features try to identify characteristics of entrepreneurial abilities through assessment personal capability, characteristics and Motivations (Haase and Lautenschlager, 2010). In fact, entrepreneurship is the key element to increase the innovation capacity in organizations and realize the competitive advantage in them (Castrogiovanni et al., 2011). Organizations can be innovative, risk takers and active through the activity of their members. The background of entrepreneurship studies shows that entrepreneurs have characteristics and attitudes that provide them with motive force and lead to their superiority over others (Matviuk, 2010). During the last few decades, researchers have been trying to discover the personality traits of entrepreneurs. The main axis of most of these research studies is motivation for advancement, creativity, self-confidence, risk taking, control focus, and accountability.

In the present study, after a comprehensive review of Entrepreneurship, studies following entrepreneurship features were selected as components of employees' entrepreneurial.

\section{Creativity}

2. Drive to Achieve

3. Internal locus control

4. Risk taking

5. Tolerance of ambiguity

6. Being independent

Creativity is the creation of new thoughts and ideas (Furnham and Bachtiar, 2010). Need for achievement means the tendency to perform works in the best way and trying to reach the peak of success (Olakitan and Ayobami, 2011). Internal locus of control means the belief that incidences are the result of human performance, not environmental 
Brazilian Journal of Operations \& Production Management

Volume 16, Número 4, 2019, pp. 617-626

DOI: 10.14488/BJOPM.2019.v16.n4.a7 factors (Arslan et al., 2009). Risk taking means acceptance of calculated risks. Ambiguity tolerance is the tolerance of ambiguous situations and making the right decisions in these circumstances (Gurol and Atsan, 2006).

\section{3. background research}

Lots of studies have been done on power and entrepreneurship and some of them are mentioned below. In marking channels, Brown et al. (1995) investigated the impact of the supplier's use of power on the retailer's commitment to the channel relationship. They adopted the mediated (i.e. reward, coercion, legal, and legitimate) and non-mediated (i.e. expertise, referent, information, traditional, and legitimate) typology of John Sonn et al. (1993).

Newstrom and Davis (1997) also argued that the coercive power is likely to have an overall negative impact on the receiver. Jalilvand and Nasrolahi Vosta (2015) investigated managers' power and affective organizational commitment. They found two major findings in this research. First, the relationships among expert power, legitimate power, reward power, referent power, and affective commitment are positive and significant. Second, the construct of the coercive power was not associated with the employees' affective commitment. The findings suggest that managers' power relates with a social exchange relationship where employees exchange positive outcomes, including strong affective commitment. When people perceive manager power, they feel more affectively attached to their organizations. In the view of Smith et al. (2010), environment has a profound impact on the human attitude toward himself/herself and others. Therefore, how the organization manager treats with individuals and the type of power used by manager contribute to the emergence of entrepreneurial behaviors as a fundamental facilitator. In their study, Jong and Hartog (2007) showed that the innovative behavior of entrepreneurs and the creative thinking of an organization's members (employees) are affected by the way in which the manager behaves toward the organization members. And the type of established communication, management style, and the power they use to deal with the organization employees play a pivotal role. Finally, Bell conducted a research in 2001 and concluded that managers and supervisors who have used appropriate management and supervisory procedures (appropriate power) have received far more performance and efficiency from their employees.

Emanating from the previous discussion, the following hypotheses were developed (see figure1):

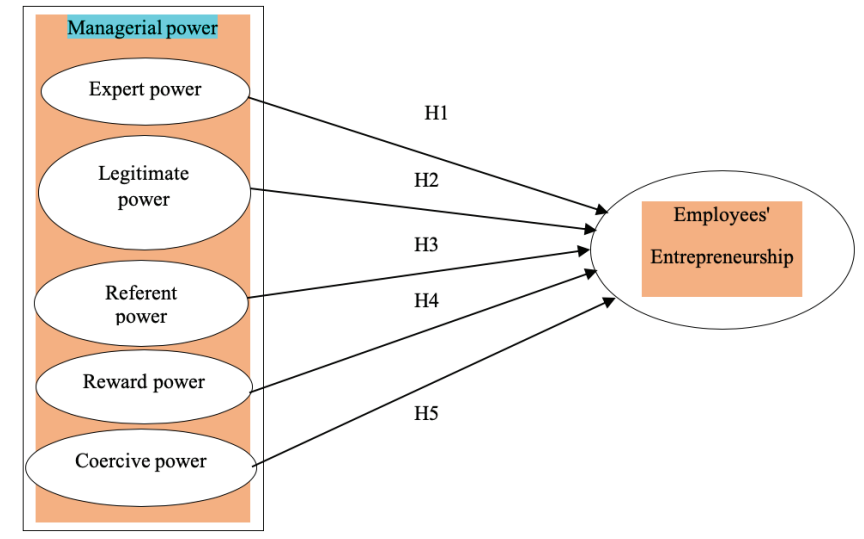

Figure 1. Conceptual model

- H1: Expert power has effect on the employees' entrepreneurship.

- H2: legitimate power has effect on the employees' entrepreneurship.

- H3: Referent power has effect on the employees' entrepreneurship.

- H4: Reward power has effect on the employees' entrepreneurship.

- H5: Coercive power has effect on the employees' entrepreneurship.

\section{METHOD}

Considering the research objective, the current research is an applied study and, regarding data collection and the data analysis method, it is a descriptive-correlational study which has analyzed data by structural equations modeling with the partial least squares (PLS) approach. It should be noted that in the structural equations, the researcher analyzes data in three steps. In the first step, the Confirmatory Factor Analysis (CFA) is investigated and if the measurement model has appropriate validity and reliability, the structural model of the research is studied. If it does not fit, the measurement model is modified and this process is performed again. As aforementioned in the current research, the measurement model (CFA) was first investigated, and after confirming the tool's validity and reliability, the structural model (path analysis) was used in order to test hypotheses.

This research focused on the public offices of Iran (in western Azerbaijan province). Data were collected from the public offices of sixth towns. The demographic variables of the respondents' sample were extracted by asking on gender, age, field of study and the number of years they have worked in organization. Table 1 shows the sample popula- 
tion for this research. All the individuals in the sample were full-time employees of the participating organizations and had good cooperation in the present study. Respondents were composed of two parts, a part of site managers and deputies who responded to the power questionnaire and the other part were the employees that responded to the Entrepreneurship questionnaire.

the questionnaires were written in Persian, and were distributed to 600 people, of whom 200 people of them were managers and 400 were employees. It should be noted that as the sampling has been done in two groups of people in the statistical population, the data packaging method was used to prepare data to be entered into the software. Questionnaires were coded before distribution, and the mean of the employees' data related to each manager was entered into the software to compare them to manager data.

All of the 200 managers returned the questionnaires filled and 390 of the 400 employees returned the questionnaires filled, thus yielding 98 percent of the responses. Average age of managers was 42 (standard deviation=6.52) and tenure was 6.45 (standard deviation=5.12) years; and for employees they were 34.82 (standard deviation=6.31) and 6.63 (standard deviation $=50.41$ ) years, respectively.

\subsection{Measures}

Managerial power - In this paper, managers' power, described by using French and Raven's (1959) power, include: coercive, expert, legitimate, referent, and reward power. French and Raven's (1959) managers' power was measured using a modified version of Hinkin and Schriesheim's (1989) power scales.

For example, the following issues were applied: My Manager can "increase my pay level" (reward), "make things unpleasant here" (coercive), "provide me with needed technical knowledge" (expert), "make me feel that I have commitments to meet" (legitimate), and make me feel personally accepted" (referent).

The managers' power was evaluated on a seven-point response scale ranging from "agree" to "disagree". The validity and reliability of the researcher-approved questionnaires have been examined. To confirm the validity of the questionnaire, three cases were checked: the apparent validity, the content validity, and the construct validity. The apparent validity was confirmed by professors' management, the content validity of the questionnaire was confirmed by CVI and CVR indicators. The construct validity of the questionnaire was approved and it is described in the next section. Hair (2011) states that in order to verify construct validity the following conditions would have existed.
1. Load factor must be significant

2. Load factor must be above 0.5

3. $A V E>0.5$

4. CR must be above 0.5 and $C R>A V E$

5. AVE > MSV

6. AVE >ASV

Table 1. Summary of descriptive statistics of respondents

\begin{tabular}{|c|c|}
\hline Demographic variable & Sample \% \\
\hline \multicolumn{2}{|c|}{ Age } \\
\hline $20-29$ years & 20 \\
\hline $30-39$ years & 25 \\
\hline $40-49$ years & 35 \\
\hline 50 and above & 20 \\
\hline \multicolumn{2}{|c|}{ Gender } \\
\hline Female & 33 \\
\hline Male & 67 \\
\hline \multicolumn{2}{|c|}{ Education level } \\
\hline Secondary & 5 \\
\hline Diploma & 15 \\
\hline Bachelor & 43 \\
\hline Master & 25 \\
\hline $\mathrm{PhD}$ & 12 \\
\hline \multicolumn{2}{|c|}{ Number of years worked with current manager } \\
\hline Less than 3 years & 13 \\
\hline 3-6 years & 20 \\
\hline $7-10$ years & 25 \\
\hline More than 10 years & 42 \\
\hline
\end{tabular}

Confirmatory factor analysis (CFA) of the managerial items (i.e. 20 items) was conducted in order to check for construct independence. Based on the results of a CFA, the data supported the independence of five factors, namely; reward power (four items, ); referent power (four items, ); coercive power (four items, ); expert power (four items, ); and legitimate power (four items, ). One item from the coercive power was dropped due to low loading of the order of or less than 0.25 .

Employees' entrepreneurship - Employees' entrepreneurship has six components and each of them was measured with four questions. These questions were made by the researcher and by all the tests that were approved. The Cronbach's for components was above 0.7. CFA results revealed that all of the items had significant positive loading on the CFA at the $p<0.05$ level. The participants were asked to assess their entrepreneurial characteristics on a sev- 
en- point response scale (ranging from "strongly agree" to "strongly disagree").

\subsection{Data collection procedures}

Before the implementation, the questionnaires were pre-tested, using a small number of respondents. Their reliability and validity were assessed. To collect the data, questionnaires were distributed and then collected by the researcher. The participants were all given the opportunity to ask questions and were encouraged to answer the survey honestly; anonymity was guaranteed and no names or other identifying information was asked.

\subsection{Validity and reliability of measures}

The Confirmatory factor analysis (CFA) was used to assess the research questions in order to determine whether the questions of this research are capable of assessing variables. As shown in the Table 2, factor loadings are featured for all the questions above 0.5 in one of the questions of the coercive power. Also other conditions of validity and reliability are satisfying for this research, as shown in the Table 2.

Table 2. Dimensionality, reliability and convergent validity statistics

\begin{tabular}{|c|c|c|c|c|c|c|c|}
\hline Variable & Items & Estimate & S.E. & $\begin{array}{l}\text { Standardized } \\
\text { estimate }\end{array}$ & C. $\mathrm{R}^{* *}$ & $\begin{array}{l}\text { Composite } \\
\text { reliability }\end{array}$ & AVE \\
\hline \multirow{4}{*}{ Expert power } & EX1 & 1.000 & - & 0.718 & - & \multirow{4}{*}{0.874} & \multirow{4}{*}{0.706} \\
\hline & EX2 & 0.785 & 0.510 & 0.970 & 22.845 & & \\
\hline & EX3 & 0.862 & 0.070 & 0.624 & 12.54 & & \\
\hline & EX4 & 0.756 & 0.052 & 0.648 & 12.05 & & \\
\hline \multirow{4}{*}{ Legitimate } & LE1 & 0.947 & - & 0.886 & - & \multirow{4}{*}{0.919} & \multirow{4}{*}{0.856} \\
\hline & LE2 & 1.000 & 0.066 & 0.628 & 16.354 & & \\
\hline & LE3 & 0.756 & 0.061 & 0.629 & 12.802 & & \\
\hline & LE4 & 0.645 & 0.106 & 0.858 & 21.896 & & \\
\hline \multirow{4}{*}{ Referent power } & RE1 & 1.000 & - & 0.665 & - & \multirow{4}{*}{0.843} & \multirow{4}{*}{0.770} \\
\hline & RE2 & 0.652 & 0.078 & 0.733 & 12.546 & & \\
\hline & RE3 & 0.623 & 0.058 & 0.811 & 23.654 & & \\
\hline & RE4 & 0.741 & 0.043 & 0.825 & 15.656 & & \\
\hline \multirow{4}{*}{ Reward power } & REW1 & 0.751 & - & 0.724 & - & \multirow{4}{*}{0.826} & \multirow{4}{*}{0.810} \\
\hline & REW2 & 1.000 & 0.065 & 0.745 & 14.456 & & \\
\hline & REW3 & 0.652 & 0.402 & 0.825 & 12.845 & & \\
\hline & REW4 & 0.762 & 0.056 & 0.734 & 14.478 & & \\
\hline \multirow{3}{*}{ Coercive power } & $\mathrm{CO} 1$ & 1.000 & - & 0.785 & - & \multirow{3}{*}{0.923} & \multirow{3}{*}{0.885} \\
\hline & $\mathrm{CO} 2$ & 0.651 & 0.0102 & 0.825 & 22.543 & & \\
\hline & $\mathrm{CO} 3$ & 0.751 & 0.107 & 0.793 & 15.989 & & \\
\hline \multirow{4}{*}{ Creativity } & CR1 & 0.745 & - & 0.721 & - & \multirow{4}{*}{0.924} & \multirow{4}{*}{0.896} \\
\hline & CR2 & 1.000 & 0.076 & 0.633 & 13.546 & & \\
\hline & CR3 & 0.736 & 0.065 & 0.654 & 16.546 & & \\
\hline & CR4 & 0.621 & 0.050 & 0.789 & 12.458 & & \\
\hline \multirow{4}{*}{ Drive to Achieve } & DR1 & 1.000 & - & 0.825 & - & \multirow{4}{*}{0.922} & \multirow{4}{*}{0.866} \\
\hline & DR2 & 0.652 & 0.042 & 0.811 & 14.36 & & \\
\hline & DR3 & 0.715 & 0.052 & 0.793 & 8.49 & & \\
\hline & DR4 & 0.687 & 0.061 & 0.785 & 5.74 & & \\
\hline \multirow{4}{*}{ Risk Taking } & $\mathrm{RI} 1$ & 1.000 & - & 0.896 & - & \multirow{4}{*}{0.910} & \multirow{4}{*}{0.879} \\
\hline & $\mathrm{RI} 2$ & 0.625 & 0.065 & 0.785 & 13.012 & & \\
\hline & $\mathrm{RI3}$ & 0.629 & 0.052 & 0.695 & 14.152 & & \\
\hline & RI4 & 0.631 & 0.042 & 0.702 & 12.12 & & \\
\hline \multirow{4}{*}{ Tolerance of Ambiguity } & TO1 & 0.741 & - & 0.895 & 22.131 & & \\
\hline & TO2 & 1.000 & 0.036 & 0.926 & 23.161 & 0842 & 0836 \\
\hline & TO3 & 0.632 & 0.118 & 0.856 & 14.512 & 0.842 & 0.836 \\
\hline & TO4 & 0.719 & 0.062 & 0.845 & 16.512 & & \\
\hline & IN1 & 1.000 & - & 0.812 & 18.121 & & \\
\hline & IN2 & 0.625 & 0.625 & 0.745 & 17.12 & & \\
\hline lo be Independent & IN3 & 0.724 & 0.532 & 0.712 & 8.215 & 0.826 & 0.812 \\
\hline & IN4 & 0.621 & 0.106 & 0.815 & 19.125 & & \\
\hline
\end{tabular}




\subsection{Analytical procedure}

Data analysis was conducted by descriptive statistics by using structural equation modeling and AMOS (version 24) structural equation program. Amos is designed to estimate and test structural equation models (SEMs). SEMs are statistical models of linear relationships among latent variables and observed variables. Its purpose is estimating the coefficients in a set of structural equations. The path coefficients are tested for significance and goodness of fit. The estimations of the parameters and the overall fit index of the measurement model are based on the maximum likelihood (ML) method. The basic conditions adopted for the use of ML estimation (Byrne, 2001) are met or approximated in the study. Furthermore, the sample is sufficiently large ( $n=195$ for manager and $n=285$ for employees). Over the recommended size of 200 cases (Medsker et al., 1994), the observed variable scale is continuous and no violations of multivariate normality are found in the survey responses. The factorial validity of the measurement model was assessed using CFA. Given the adequate validity coefficients of those measures, the number of indicators in the model was reduced by creating a composite scale for each latent variable (Hair et al., 1995).

The measurement of the suitability of the model was used to evaluate the fit of the structural model. To estimate the suitability of the model (goodness of fit) indices (GFI) for measurement and structural model, $\mathrm{X}^{2}$-test was used.

In addition, the root mean square error of approximation (RMSEA) was used as an absolute fit index. The incremental fit index (IFI), the Tucker-Lewis index (TLI), and the comparative fit index (CFI) were used as an absolute fit index. The incremental fit index (IFI), the Tucker-Lewis index (TLI), and the comparative fit index (CFI) were used as incremental fit indices. For GFI, AGFI, CFI, and TLI, coefficients closer to unity indicate a good fit, with acceptable levels of fit being a bare 0.90 (Hair, 2011). Root mean square residual (RMR) and RMSEA evidence of good fit are considered to be values lower than 0.05 ; values from 0.05 to 0.10 are indicative of moderate fit and values greater than 0.10 are taken to be evidence of a poorly fitting model (Browne and Cudeck, 1993). Standardized estimates were used in reporting the causal relationships between the exogenous and endogenous constricts.

\section{RESULTS}

Table II reports the estimate, T-value, and Result Hypotheses. Moreover, figure 3 shows results of the best fit structural equation model. The analysis shows that the structural model of figure 3 fits the data reasonably well, with $\mathrm{x}^{2}=1005 / 003 ; \mathrm{df}=51\left(\mathrm{X}^{2} / \mathrm{df}=19.705 ; \mathrm{p}=0.000 ; \mathrm{GFI}=0901\right.$; $A G F I=0.951 ; C F I=0.962 ; \mathrm{NFI}=0.904 ; \mathrm{IFI}=0.995 ; \mathrm{TLI}=0.961 ;$ $\mathrm{RMR}=0.053$; and RMSEA=0.048). Standardized path esti- mates are provided to facilitate the comparison of the regression coefficients.

Table 2. Result Hypotheses

\begin{tabular}{|c|c|c|c|}
\hline Hypotheses & Estimate & T value & Result \\
\hline $\begin{array}{c}\text { 1. expert power employ- } \\
\text { ees' entrepreneurship }\end{array}$ & 0.35 & 3.08 & accept \\
\hline $\begin{array}{c}\text { 2. legitimate power } \\
\text { employees' entrepre- } \\
\text { neurship }\end{array}$ & 0.117 & 7.15 & accept \\
\hline $\begin{array}{c}\text { 3. Referent power } \\
\text { employees' entrepre- } \\
\text { neurship }\end{array}$ & 0.568 & 5.66 & accept \\
\hline $\begin{array}{c}\text { 4. Reward power employ- } \\
\text { ees' entrepreneurship }\end{array}$ & 0.754 & 2.43 & accept \\
\hline $\begin{array}{c}\text { 5. coercive power em- } \\
\text { ployees' entrepreneur- } \\
\text { ship }\end{array}$ & -0.171 & -1.22 & reject \\
\hline
\end{tabular}

As reported in Table 2, All hypothesis were accepted, except H5. Thus, all components of the managers' power predict employees' entrepreneurship, except the coercive power. Reward power had the greatest effect on employees' entrepreneurship and the legitimate power had the least effect on employees' entrepreneurship.

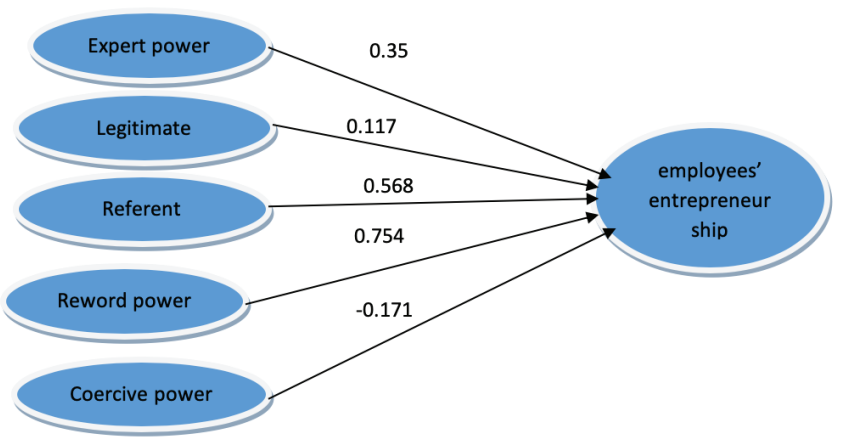

Figure 2. Standardized estimates of predicted model

\section{DISCUSSION AND CONCLUSION}

This paper has investigated the effect of managers' power on employee's entrepreneurship in the public offices in Iran. Becoming aware of the influence of power on an organization is an important step in the achievement of the organization (Popovich and Warren, 2010). It is also necessary to be aware of the bases of employees' behavior and, this way, employees' entrepreneurship is strengthened.

It must be understood that Entrepreneurship is one of the solutions for the collapse of today's organizations. The results of the present study show that all components of the managers' power had a positive and significant impact on employee's entrepreneurship except the coercive power. 
Brazilian Journal of Operations \& Production Management

Volume 16, Número 4, 2019, pp. 617-626

DOI: 10.14488/BJOPM.2019.v16.n4.a7
This means that expert power, legitimate power, reward power, and referent power (personality power) have a positive and significant influence on employees' entrepreneurship in the public offices. The power of managers in some studies has been investigated but the researcher did not find any research that investigated this variable with entrepreneurship. Some researchers (Malhotra et al., 2007; Williamson et al., 2009; Newman \& Sheik, 2012; Tornikoski, 2011; and Jalilvand and Nasrolahi Vosta, 2015) have found that managers' power has positive and significant influence on organizational commitment. Other researchers, such Rajan and Krishnan (2002) and Popovich and Warren (2010) have verified that power influence on other variables is similar to this research. Many components of power have had positive influence on dependent variables. In fact, the use of expert, legitimate, reward, and referent power will strengthen employees' entrepreneurship. By giving reward, law enforcement, charismatic, and expertise properties, managers can provide the motivation for employees' entrepreneurship. Thus, manager's use of reward power and legitimate power provides the extrinsic motivation for employees' entrepreneurship and, with the use of expert power or referent power, the intrinsic motivation for employees' entrepreneurship is provided.

As these intrinsic factors become more central, extrinsic factors such as rewards and legal action may become less important (Brown et al., 1995).

The findings are useful for managers to affect the employees in order to strengthen the entrepreneurial characteristics of employees. This study had showed that reward power has a positive and significant impact on employees' entrepreneurship. By giving a reward to employees, managers create the extrinsic motivation for employee's entrepreneurship in organizations. When reward power is used in an organization, it can be converted into a strong motivator (Newman and Sheikh, 2012). Reward power does not need to be monetary or tangible compensation to work, as managers can give various intangible benefits as rewards (Malhotra et al., 2007). The study shows that expert, referent, and legitimate power have a positive and significant effect on employees' entrepreneurial. By using expertise, referent, and legitimate power, managers increase positive attitudes toward the organization by increasing the positive relationship between them and the employees (Brown et al., 1995).

Finally, our study revealed that coercive power is not effect on employees' entrepreneurial. However, Managers should remember that coercive power might be a negative impact on employees' entrepreneurship.

Coercive power decreases employees' satisfaction, thus leading employees not to like showing entrepreneurial behavior.
The use of coercive power results in an atmosphere of insecurity or fear and a decline in productivity and creativity (Harris and Hartman, 2002). Therefore, if you want to have an organization with employees' entrepreneurship, you should not make use of such coercive power. Finally, with regard to the Results mentioned, managers should use power in a positive direction to be able to encourage entrepreneurship among employees and manage their organization in the face of difficult conditions. More specifically, given the path coefficients obtained from the research structural model, in order to have a greater influence, it is suggested that government organizations under study use referent power, and especially, reward power that has higher than average path coefficients to strengthen entrepreneurship in employees, so that they can increase entrepreneurial characteristics and lead to the occurrence of entrepreneurial behaviors in employees. For example, by identifying the rewards affecting employees, such as job promotion, increasing responsibility, and financial rewards the entrepreneurial process is accelerated, or the positive relationship with employees is strengthened by gaining trust, secrecy, trusteeship and honesty, and, by creating the positive feeling in employees, the way is paved to create entrepreneurial characteristics in workers and increase an entrepreneurial behavior in them. Additionally, it is emphasized that coercive power should not be used at all and whenever the use of coercive power is inevitable, it should be justified to employees, so that they can understand that it has been used as the last resort to improve and restore order in the system.

\section{LIMITATIONS AND SUGGESTIONS FOR FUTURE RESEARCH}

One of the limitations of this research was gathering data, firstly because statistical society was vast and all offices must be considered, and secondly, because there were a lot of problems in data distribution and collection because of exciting special rules in each office that has to coordinate separately with each of them. The second limitation is about some variables such as Iran's economic conditions and culture of results. Therefore, it is recommended for future researchers to carry out this research in one of the provinces that is united in terms of ethnicity. And some variables should also be considered, such as culture.

\section{ACKNOWLEDGEMENT}

This work was supported by the West Azerbaijan Governor of Iran. Therefore, we appreciate authorities and managers for their support. 


\section{REFERENCES}

Analoui, F., Moghimi, S. M., and Khanifar, H. (2009), "Public sector managers and entrepreneurship in Islamic republic of Iran", Journal of Management Development, Vol. 28, No. 6, pp. 522-532.

Arslan, C., Dilmac, B. H., and Hamarta, E. (2009), "Coping with stress and trait anxiety in terms of locus of control: $A$ study with Turkish university students", Social behavior and personality, Vol. 37, No. 6, pp. 791-800.

Braga, F. J. A., Silvestre, F. S., and Oliveira, U. R. (2018), "Analysis of individual micro-entrepreneur vision from the perspective of financial management", Brazilian Journal of Operations and Production Management, Vol. 15, No. 2, pp. 182-192. DOI: https://doi.org/https://doi.org/10.14488/BJOPM.2018.v15.n2.a2

Brown, J. R., lusch, R. F. and Ni cholson, C.Y. (1995), "Power and relationship commitment: their impact on marketing channel member performance", Journal of Retailing, Vol. 71, No. 4, pp.3 63-392.

Browne, M.W. and Cudeck, R.(1993), "Alternative way of assessing model fit", in Bollen, K. A. and Scott long, J. (Eds), Testing structural Equations models, Sage, Newbury Park, CA, pp. 136-162.

Byrne, B.M. (2001), Structural Equation modelling with AMOS: Basic concepts, Applications and programming, Lawrence Erlbaum Associates Inc., Newyork, Ny.

Castrogiovanni, G. J., Urbano, D., and Laras. J. (2001), “Linking corporate entrepreneurship and human resource management in SMEs", International Journal of Manpower, Vol. 32, No. 1, pp. 34-47.

Cho, S. (2006), "The power of public relations in media relations: A national survey of health practitioners", Journalism and Mass Communication Quarterly, Vol. 83, No. 3, pp. 563580.

Coyle-Shapiro, J.A.M. and Morrow, P.C. (2006), "Organizational and client commitment among contracted employees", Journal of Vocational Behaviour, Vol. 68, No. 4, pp. 416-431.

Daft , R. L. (2000), Management. 5th ed., Dryden Proess, New York, NY.

De Dreu, C. K. W. and Van kleef, G. A. (2004), "The influence of power on the information search, impression formation, and demands in negotiation", Journal of Experimental Social Psychology, Vol. 4. No. 3, pp.303-319.

Drea, J. T., Bruner, G. G., Hansel, P. J. (1993), “Companing alternative measures of the French and Raven power bases", The Journal of Personal Selling and Sales Management, Vol. 13, No. 4, pp. 73-80.

Erkutlu, H., and Chafra, J. (2016), "Impact of behavioral integrity on organizational identification the moderating roles of power distance and organizational politics", Management Research Review, Vol. 39, No. 6, pp. 672-691.

French, J.R.P. and Raven, B.H.(1959), "The basis of social power", In Cartwright, D. (Ed), Studies in social power, Institute for Social Research, University of Michigan, Ann Arbor, MI, pp. 150-167.

Furnham, A., and Bachtiar, V. (2008), "Personality and intelligence as predicators of reativity", Personality and Individual Differences, Vol. 45, No. 7, pp. 613-617.

Galinsky, A:D., Gruenfeld , D.H. and magee, J.C. (2003), "From power to action", Journal of Personality and Social Psychology, Vol. 85, No.3, pp. 453-466.

Guinote, A. (2010), "In touch with your feelings: power increases reliance on bodily information", Social Cognition, Vol. 28, No.1, pp.110-121.

Gurol, Y., and Atsan, N. (2006), "Entrepreneurial characteristics amongst university students some insights for entrepreneurship education and training in Turkey", Education and Training, Vol. 48, No. 1, pp. 25-38.

Haase, H., and Lautenschlager, A. (2010), "The teach ability dilemma of entrepreneurship", International Entrepreneurship and Management Journal, Vol. 6, No. 1.

Hair, J. F., Ringle, C. M., \& Sastedt, M. (2011), "Pls- SEM Indeed a Silver bullet", Journal of Merketing Theory \& Practice, Vol. 19, No. 2, pp. 135-147.

Hair, J.F., Anderson, R.E., Tathan, R.L. et al. (1995), Multivariate Data Analysis with Reading, 4th ed., Prentice-Hall, Englewood cliffs, NJ.

Harris, O.J. and Hartman, S.J.(2002), Organizational Behavior, The Hawoth Press, Binghamton, Ny.

Hinkin, T. R., \& Schriesheim. C. A. (1989), “Development and application of New Scales to measure the French \& Raven (1959) bases of social power", Journal of Applied psychology, Vol. 78, No. 1, pp. 561-567.

Jalilvand, M.R. and Nasrolahivosta, L. (2015), “Examining the relationship between Managers powerandaffective organizational commitment empirical study in the sport Sector of Iran", Sport, Business and management: An International Journal, Vol. 5, No. 4, pp. 344-364.

Jena, S., \& Sahoo, C. K. (2014), “Improving Managerial performance: a study on entrepreneurial and leadership competencies", Industrial and Commercial Training, Vol. 4, No. 3, pp. 143-149.

Jong, I. and Hartog, D. (2007), "How leaders influence employees innovative behavior?", European Journal of Innovation Management, Vol. 10, No. 1, pp. 41-64.

Keltner, D., Gruenfeld, D.H. and Anderson, C. (2003), "Power, approach, and inhibition", Psychological Pewiew, Vol. 110, No.2, pp. 265-284. 
Brazilian Journal of Operations \& Production Management

Volume 16, Número 4, 2019, pp. 617-626

DOI: 10.14488/BJOPM.2019.v16.n4.a7
Lewin, K. (1941), "Regression, retrogression and development", University of Iowa Studies of Child Welfare, Vol. 18, No. 1, pp. 1-43.

Malhotra, N., Budhwar, P. and Prowse, P. (2007), "Linking rewards to commitment: an empirical investigation of four ukcall centres", International Journal of Human Resource Management, Vol. 18, No. 12, pp. 2095-2128.

Matviuk, S.G. (2010), "A study of Peruvian entrepreneurs, leadership expectations", Journal of American Academy of Business, Vol. 16, No. 1, pp. 65-70.

Medsker, G.J., Williams, L.J. and Holahan, P.J. (1994), “A review of current practices for evaluating causal models in organizational behavior and human resources management research", Journal of management, Vol. 20, No. 5, pp. 439-464.

Minatogawa, V., Franco, M., Pinto, J. et al. (2018), "Business model innovation influencing factors: an integrative literature review", Brazilian Journal of Operations and Production Management, Vol. 15, No. 4, pp. 610-617. DOI: https://doi. org/https://doi.org/10.14488/BJOPM.2018.v15.n4.a14

Mintzberg, H.(1983), Power in and Around organization Englewood cliffs, Prentice-Hall, N.J.

Montana, P.J, and Charnov, B. H. (2008), Management: Leadership and Theory, 4thEnglished., Barron's Educational Series Inc., Huppauge, NY.

Muhammad, A., Akbar, S. and Dalziel, M. (2011), "The journey to develop educated entrepreneurs: prospects and problems of Afghan businessmen", Education+ Training, Vol. 53, No. 5, pp. 433-447.

Newman, A. and Sheikh, A.Z.(2012), “Organizational rewards and employee commitment: achinese study", Journal of Managerial Psychology, Vol. 27, No.1, pp.71-89.

Newstrom, J. W. and Davis, K. (1997), Organizational Behave our: Human Behave our at work, 10thed., MCG Raw-Hill, Irwin. Ny.

Olakitan, O., and Ayobami, A.P. (2011), "An Investigation of personality on entrepreneurial Succes", Journal of Emerging Trends in Economics and management Science, Vol. 2, No. 2, pp. 95-103.

Peters, T. (1999), The Circle of Innovation, Vintage Books, New York.
Pfeffer, J. (1994), Stock Image Competitive Advantage Through People: Unleashing the Power of the Work Force, Harvard, Harvard Business School.

Pinnow, D. F. (2011), Leadership-What Really Matters, Springer Heidelberg Dordrecht, London and New York, NY.

Popovich, P. M. and Warren, M.(2010), "The role of power in sexual harassment as a counterproductive behavior in organizations", Human Resource Management Review, Vol. 20, pp. 45-53.

Rajan, S. R. and Krishnan, V.R. (2002), "Impact of gender on influence, power and authoritarianism", women in management Review, Vol. 17, No.5, pp.197-206.

Sandhu, S.M., Sidique, F.S. and Riaz, S.(2010), "Entrepreneurial barriers and entrepreneurial inclination among Malaysia post graduate students", International Journal of Entrepreneurial Behavior and Research, Vol. 17, No. 4, pp.428-229.

Schumpeter, J.A. (1934), The Theory of Economic Development, Harvard University Press, Cambridge, MA.

Smith, A. J, Collins, L .A., and Hannan, P. D. (2010), "Creative disciplines education: a model for assessing ideas in entrepreneurship education?", Education and Training, Vol. 48, No. 2, pp. 555-564.

Thibaut, J.W. and kelley, H.H.(1959), The social psychology of Groups, Wiley, New York, Ny.

Tornikoski, C. (2011), "Fostering expatriate affective commitment: a total reward perspective", Cross Cultural Management: An International Journal, Vol. 18, No 2, pp. 214-235.

Vescio, T.K., Snyder, M. and Butz, D.A. (2003), "Power in stereotypically masculine domains: a social influence strategy X stereotype match model", Journal of Personality and Social Psychology, Vol. 85, No.6, pp.1062-1078.

Watson, G.W. and Papamarcos, S.D. (2002), "Social capital and organizational commitment", Journal of Business and Psychology, Vol. 16, No. 4, pp. 537-552.

Weber, M., Henderson, A. M., Parsons, T. (1947), "The theory of social and economic organization", Oxford University Press, New York.

Williamson, I. O., Burnett, M.F. and Bartol, K.M. (2009), "The interactive effect collectivism and organizational rewards on affective organizational commitment", Cross Cultural Management: An International Journal, Vol. 16, No. 1, pp. 28-43.

Received: 16 Nov 2018

Approved: 15 May 2019

DOI: 10.14488/BJOPM.2019.v16.n4.a7

How to cite: Mahbobkhah, F. (2019), “The effect of managers' power on employees' entrepreneurship: an empirical study in the public offices of Iran", Brazilian Journal of Operations \& Production Management, Vol. 16, No. 4, pp. 617626, available from: https://bjopm.emnuvens.com.br/bjopm/article/view/635 (access year month day). 